\title{
Oriental Music Boxes in Iowa
}

\section{By Mary Lou Pitlick}

Give an American a stone slab engraved with Egyptian hieroglyphics, and he would probably shrug his shoulders in bewilderment. Let a Scotchman attempt to interpret some intricate Chinese script; or a Javanese native a page of an English newspaper, and he would be more than slightly puzzled. But let an Egyptian play a melody on his reed flute, and the modern American might mistake it for a theme from a Stravinsky composition. Music as a means of communication is universal, as adequately attested to by a collection of musical instruments on exhibit at the Davenport Public Museum.

Surrounded by stuffed white owls and colonial spinning wheels, the collection stems from the four corners of the world. From Java comes a bamboo percussion instrument consisting of a hollow bamboo reed, approximately twelve inches long and two inches in diameter. Two more reeds, one the size of the first and the other half as large, are perpendicularly inserted in its slots and secured by a bamboo frame. When shaken, the two perpendicular reeds vibrate in the slots, producing a hollow, rattling sound. The smaller reed vibrates an octave higher than the larger.

A Chinese drum was given to the museum by $\mathrm{Dr}$. Slack, through the Koehler estate. Heavy rawhide is fastened to the twelve-inch-in-diameter cylinder by hand-wrought metal nails. A work of pictorial art as well as a musical instrument, the rawhide is exquisitely engraved with birds in oriental pastels delicately resembling modern abstract art.

In reference to the instruments of the Orient, it is well to recall that Oriental music is essentially melodic and seldom adds a second part or an accompaniment in chords, as does the harmonic music of the Occident, a 
fact which probably accounts for the unusual instruments

Also from China comes a "sho," or cluster-flute. Given to the museum in 1925 by C. E. Russell, the instrument consists of a black-lacquered bowl about the s1ze of a teacup, from which projects a mouthpiece tipped in ivory. Inserted perpendicularly into holes in the top of the bowl are seventeen hollow reeds varying in length from eight inches to twelve inches. At the base of each reed is a tiny hole over which the player may place his fingertip to stop the sound.

An Egyptian flute, purchased in Abydos, Egypt, in 1896, consists of two parallel hollow reeds, each a foot long and bound together with cord. The musician blows into the ends of the reeds and places his fingers over one or more holes in each reed to produce various tones.

A Scottish flute similar to that from Egypt was given to the museum by Elizabeth Putnam in 1903. Instead of two reeds, however, two hollow cylinders of heavy wood are bound together with metal bands. There are seven holes in each cylinder over which the player may place his fingertips to stop the flow of air and produce various tones, as in the Egyptian flute and the Chinese "sho."

A "pipa" or pear-shaped guitar, from Peking, China, is made of teakwood. About three feet long, the flat soundboard secures twelve ivory-tipped ebony frets over which pass four strings. The curved scroll of the neck is decorated with inlays of bone engraved with oriental flowers and intricate Chinese script. The mahogany pegs which adjust the length of the strings are also tipped with ivory and intricately carved. The "pipa," bearing close resemblance to the American mandolin, was given to the museum by C. A. Ficke, one of Davenport's earliest attorneys who, with his wife, traveled around the world some three or four times.

A Japanese "koto," from the early Tokugawa dynasty of the seventeenth century, was obtained by C. E. Russell in 1925. It consists of a hollow soundboard with a flat back and curved top. Only about a foot wide, thir- 
teen strings run its full five-foot length over inverted u-shaped frets. The instrument is played by means of ivory picks on the thumb and second finger of the right hand, while the left hand regulates the length of the strings as on the violin.

Also from Japan comes a three-string musical instrument with a cylindrical sounding box covered with silver-colored snakeskin. It has movable ivory frets over which the three gut strings pass and are fastened to an ornately carved scroll.

The "Tan ch'in" is a two-string violin from Mandalay, Burma. Its bowl-shaped sounding box is a dried, hollow gourd worn brown with time and use. Its teakwood neck is about three feet long, securing the two strings which pass over ivory-tipped frets to dual pegs which pass through the upper end of the neck.

From the Occidental world is an Irish harp given to the museum by a Davenport antique shop when it went out of business some years ago. About four feet high the dark mahogany harp is constructed much like the gold harp of the contemporary concert stage, although the Irish harp has no pedals to regulate the length of the strings and little decoration. The only ornament is a knob resembling a drawer handle atop the hollow sounding box.

"To Julia Smith Duncan from dear Mother, 1848," is written in flowing script with faded brown ink inside a music box. The worn label is also inscribed with selections played by the intricate mechanism inside:

\section{French Songs-}

Triste Valse d'Elise

Belle Galoppe, No. 5 Nouvelle English Songs-

Draw the Sword, Scotland

O Give Me Back My Loyal Steed

The box itself is about a foot long and of burnished, scarred wood. A heavy iron key winds the mechanism, which consists of a rotating metal cylinder bearing pinhead metal projections struck by a row of tiny metal needles fastened to the side of the box. The end product is a delicate, tinkling sound. 
Perhaps the Chinese drum could not adequately substitute for the tympani in the percussion section of a modern symphony, nor could the "koto" in the string section take the place of the cello; but each of the above instruments represents well the people and culture of its respective country and resounds its melody in the symphony of man's communication of his thoughts.

\section{The Big Dexter Boulder}

Some of the huge granite blocks constituting the water-table cap of the foundation of the Iowa state capitol at Des Moines have a slightly reddish shade, while the most are gray, particularly the larger ones. These reddish stone blocks were secured by the contractor when a shortage of the right stones was discovered. The granite used in the construction of this magnificent Iowa edifice mostly came from New Hampshire.

How to match the stone already set without too much delay was a question. It was solved by information received that out in a farm pasture near Dexter, Iowa, was a huge granite boulder as large as a haystack, and of light shade. On examination by the contractor and Roger Finkbine, the superintendent of construction, the material was found to be excellent and the shade or color only slightly off from that of the material already in place.

A group of competent stone-cutters with hoisting equipment journeyed to Dexter and went to work upon the granite boulder, which had been deposited on the prairie by one of the glaciers in a previous age. Quickly the desired additional blocks were fashioned and hauled to Des Moines, meeting the needs of the contractor in completion of the water-table of the capitol structure.

These reddish stones can be spotted today in the cap tier of the capitol foundation-some here and some there, usually the smaller sized blocks, and clearly distinguishable from the original gray stones shipped from the east. 
Copyright of Annals of Iowa is the property of State of Iowa, by \& through the State Historical Society of Iowa and its content may not be copied or emailed to multiple sites or posted to a listserv without the copyright holder's express written permission. However, users may print, download, or email articles for individual use. 